\title{
Project Based Learning Applied to Technical Drawing
}

\section{Eduardo Ferro dos Santos', Bruna Caroline Marques Gonçalves², Karine Borges de Oliveira², Messias Borges Silva1}

\author{
${ }^{1}$ Lorena School of Engineering, University of Sao Paulo (USP), Sao Paulo, Brazil \\ ${ }^{2}$ Production Engineering Department, Sao Paulo State University (UNESP), Sao Paulo, Brazil \\ Email: eduardo.ferro@usp.br, messias@dequi.eel.usp.br, karineborges@feg.unesp.br, brunacarolinebcmg@gmail.com
}

How to cite this paper: dos Santos, E. F., Gonçalves, B. C. M., de Oliveira, K. B., \& Silva, M. B. (2018). Project Based Learning Applied to Technical Drawing. Creative Education, 9, 479-496.

https://doi.org/10.4236/ce.2018.93034

Received: February 13, 2018

Accepted: March 24, 2018

Published: March 27, 2018

Copyright $\odot 2018$ by authors and Scientific Research Publishing Inc. This work is licensed under the Creative Commons Attribution International License (CC BY 4.0).

http://creativecommons.org/licenses/by/4.0/ (c) (i) Open Access

\begin{abstract}
New technological advances have been challenging professionals in education area to reach the new generation of students. Since this new generation is surrounded by this new technology, it is mandatory to associate new practices and teaching methods to their education plan. In this way, educators must reflect not only on their usual pedagogical practices but also in the efficacy of the method that has been practiced in the teaching and learning process. Technical Drawing is a discipline that takes place in High School programs in addition to Technical and Higher Education. It is directly influenced by this technological advance, once the student goes from the draw in the paper to the draw in computers during the classes and is encouraged to execute the projects that arise from the step-by-step draw. In this context, this work aimed to show a study performed during the Technical Drawing discipline to report a new structure in the educational methodology related to project-based learning. The focus of this study was to encourage students to develop a greater interest in engineering using project based learning and use this as a method for learning.
\end{abstract}

\section{Keywords}

Project Based Learning, Active Methodologies in High Education, Technical Drawing

\section{Introduction}

The current technological development has stimulating advances in all fields of knowledge. New technologies have been emerging every day and allow the quick satisfaction of the market needs along with the creation of new market segments. 
To assure updated knowledge to be shared in the classroom and competitive professionals, the teaching-learning processes must monitor this development. In this way, new applications, new strands, and a way applied to the development of products and services, involving various fields of knowledge as a way of stimulating the labor market to represent new strategies to approach the students of the real world, consolidating their interest to the classes.

According to Meyer and Nascimento (2011), developed countries have been showing a great concern regarding the attraction of excellent students to areas related to Technology and Engineering. The improvement of the technology in industries and services has been demanding high skilled professionals. Due to the rapid technological advances, there is a lack of availability of such professionals in the market. Therefore students must be attracted and prepared to act to occupy these places. The development of Technology and Engineering areas strongly depend on the "attractiveness policy" that makes the high intellectual level of students to choose careers in excellent schools. One of the most successful initiatives on this subject is the "Harvard Project Physics" that created attractive and interactive ways for teaching physics for high school students during the 1960's (Pena, 2012).

The main reason for evasion in engineering in different universities is the abandonment of the course, often in the first period, due to two main factors: (i) students who get the approval in more than one university, for the same course or not. These students enroll in all universities where they got approval. However they develop the studies in only one of them, leaving the other(s); and (ii) students who start the course and realize they have another vocation or difficulty in exact sciences, abandoning the course. Most students are very young, teenagers, and usually, they are forced to choose a profession, sometimes without knowing what the profession does (Campello \& Lins, 2008; dos Santos, Nascimento, \& Rios, 2000; Lins et al., 2014).

In this scenario, two major challenges must be minimized. The first challenge regards the encouragement of the young from High School to choose engineering courses as a degree. The second challenge is to minimize the dropouts during the first years of the course. To solve these problems, researchers in teaching and learning methods have been focusing their efforts on the development of techniques that help to solve the difficulties on teaching (Kolmos, De Graaff. \& Du, 2009; Pereira et al., 2017; Santos et al., 2017; Santos et al., 2015; Santos, Silva, \& Barreto, 2015). Also, they propose the monitoring of technological developments. The easiness of the access to information and use of computer resources facilitate the development and application of methods that prioritize the research and the real problems as activities that create knowledge. In this way, the educator must encourage the student through the practice and application of various methods besides project management tools as a new teaching-learning methodology. An example of these methodologies is active learning methodologies, especially the Project-Based Learning (PBL). 
The PBL is a teaching and innovative learning method. It focuses on the concepts and principles of one or more subjects, involving students in research activities to solve relevant projects and problems, allowing the student to work independently to build their knowledge based on projects that involve real situation. It allows educators to teach classes with greater proximity to students and identify the current needs. As a result, this method allows a better preparation of professionals.

In Technical Drawing, the advance of the theoretical-practice technology is presented to the students through the evolution of applications from drawing in pencil and paper to new current applications assisted by computer and network projects, which is underexplored by teachers and students involved in this discipline. This discipline should be explored as a tool for projects. However the teaching of Technical Drawing does not make any relation to the development of a project (Santos et al., 2015). This subject has been handled by teachers as pure science, and the classes are usually based on reading and interpretation, requiring a great effort of abstraction for their learning. As long as the major goal in the teaching of Technical Drawing is to arouse the student ability for abstraction besides the development of a three-dimensional vision along with three-dimensional reasoning, a paradoxical is identified.

In this way, this paper proposes an innovative methodology related to the teaching of projects, especially for the Technical Drawing course, to link this Science to their original objective: the project. Thus, the techniques of representation, projections and descriptive methods are the main focus of the project troubleshooting.

\section{Actives Methodologies to Teaching and Learning}

It is necessary to update teachers regarding the necessity of pedagogical knowledge and skills. The complexity of the educational scenario show that teaches the concepts and theories is not enough. It is important and essential to educate students to manage their knowledge, acquiring ability related to research, problem solution, projects, team spirit, analysis, synthesis, and communication.

In the traditional method of teaching, the student is in a position of passive agent in the learning process, trying to absorb the knowledge and the teacher's experiences. The use of exhibition classes, in which the teacher exposes the subject and assesses the students from the contents absorbed in lessons and during the time utilized for the study is interesting for both didactic-pedagogical issues and economic-administrative issues. This is the most economical, flexible and rapid way of transmission of knowledge and may be used by any professional with knowledge of the subject, even those who have no pedagogical knowledge. On the other hand, new teaching methods are more dynamic, and the student occupies the position of active agent in the learning process. They are stimulated using activities that contribute to their abilities related to initiative and discovery, creating continuous and dynamic learning. The teacher helps the student to 
learn, not only teaches.

The learning methodology based on projects or problems is characterized by the use of questions and real-world cases to encourage students to develop critical thinking and skills to solve problems, acquiring knowledge about the essential concepts of the area in question (Nanda \& Manjunatha, 2013). The method may be implemented in the whole course; as a partial educational strategy or even in separate subjects. In this method, the student is exposed to motivating situations in tutorial groups where, through a project, they are led to define goals of learning related to the topics listed in the curriculum. One of the main fundamentals of this method is to teach the student to learn in different ways. In addition to the constant updated, the student develops agility to solve problems and creativity to explore new organizational methods. As a result, the student develops independence, a permanent study attitude, and real learning. Moreover, the acquired knowledge is kept longer (Long \& Qin, 2014). Several authors applied the PBL and Active Learning Methods with important results, as shown in Table 1.

In Technical Drawing, the application of PBL can also be facilitated using design software computer-aided (CAD_Computer Aided Design). The use of this technology has created a great change in the development of engineering projects, given its qualities not found in the design manual forms, such as speed, efficiency, and ease of review (Ye et al., 2014), as well as providing opportunities for viewing objects in three dimensions from orthographic views and perspectives (Cao et al., 2013).

\section{Action-Research}

The methodology of this study defines action-research as a type of empirical research, which is conceived and developed in association with an action or solving of a collective problem, in which researchers, and participants are involved in a cooperative or participatory way. It was possible to choose this method due to the direct participation of the researcher along with the target of analysis (Santos \& Lima, 2012). In this way, the researcher assumes the role of leader, offering structured activities under the principles of the method and leading the development of the conceptual research and reports from the students.

The population of this study was composed of first-year High School students (34 students). The variables of the research were the application of the learning method based on projects and the students' perception of the dynamics of the method. The main activity planned was divided over twelve months of implementation. Classes were given over 40 weeks, totalizing 80 hours. It was the time required for implementation of the subject content in an annual-base discipline.

Students should provide not less than one concrete solution to the proposed theme. Even though the project has a defined thematic, there is not a single solution, what represents a challenge for both, students and teachers. The following steps were applied (i) present the selected topic; (ii) provide technical specification 
Table 1. Research on PBL and active learning methods.

\begin{tabular}{|c|c|}
\hline Authors & Results \\
\hline Silva et al. (2016) & $\begin{array}{l}\text { PBL was applied in the revolution of free educational robotics in the public school environment, using } \\
\text { electronic waste instead of commercial solutions for building robots, allowing students to enlarge their view } \\
\text { about technological applications in their social and educational context. Through this method, the authors } \\
\text { found that robotics is an activity capable of keeping young people away from the streets and offer them } \\
\text { multidisciplinary training, reducing their vulnerability. }\end{array}$ \\
\hline Ausin et al. (2016) & $\begin{array}{l}\text { A new educational experience in the concept of PBL and the use of information and communications } \\
\text { technologies was reported by these authors. Students were satisfied with the radio program created } \\
\text { during the project, and they had agreed on the project's usefulness. }\end{array}$ \\
\hline Lee et al. (2015) & PBL application improved the social skills of students and their ways of perceiving interpersonal conflicts. \\
\hline Hung et al. (2014) & $\begin{array}{l}\text { These authors conducted a study investigating the effects of PBL in a project and reported improvements in } \\
\text { skills of students regarding questioning taking into account different levels of prior knowledge. }\end{array}$ \\
\hline Wiek et al. (2013) & $\begin{array}{l}\text { PBL was used to demonstrate that students have built the capability to solve sustainability problems in the real } \\
\text { world, with competence to cooperate with partners in government, business and civil society. }\end{array}$ \\
\hline $\begin{array}{l}\text { Dolmans \& } \\
\text { Gijbels (2013) }\end{array}$ & $\begin{array}{l}\text { PBL effects on different approaches to student learning were investigated. It was reported that PBL might } \\
\text { promote desired approaches to learning. }\end{array}$ \\
\hline Tan et al. (2015) & $\begin{array}{l}\text { The results of research experience with students involved in PBL were presented in oral and written poster } \\
\text { presentations. }\end{array}$ \\
\hline Chao et al. (2015) & $\begin{array}{l}\text { They showed that PBL has a positive effect on the transfer of learning. Authors referred the benefits of a } \\
\text { learning approach applied to students in an introductory level curriculum on computer-aided design, } \\
\text { building a bridge between the learning and the curriculum at High School Engineering Education. }\end{array}$ \\
\hline Kim \& Lee (2014) & $\begin{array}{l}\text { Proposed a method for teaching information processing skills based on a learning model based on problems, } \\
\text { and tested in Elementary School students. The author mentions that PBL has an improved methodology for } \\
\text { the teaching of skills of information processing. }\end{array}$ \\
\hline $\begin{array}{l}\text { Jerzembeka \& } \\
\text { Murphya (2013) }\end{array}$ & $\begin{array}{l}\text { These authors applied PBL in primary school students, checking their effect on the academic and personal } \\
\text { development. They reported the effects of the method and its application efficiency in the school environment. }\end{array}$ \\
\hline Wilder (2015) & $\begin{array}{l}\text { This author reported the impact of PBL on academic performance in high school through a systematic review. } \\
\text { The effectiveness of PBL in Secondary education was highlighted. }\end{array}$ \\
\hline Moreno et al. (2013) & $\begin{array}{l}\text { They investigated the conceptions of teachers in biological areas: Biology, Physics, and Chemistry) at PBL. Also, } \\
\text { it was demonstrated that teachers understand the methodology and classified as an interesting way of teaching. } \\
\text { However, they refused the application due to it requires a more comprehensive training or in-service training. }\end{array}$ \\
\hline $\begin{array}{l}\text { Granzotti \& } \\
\text { Barroso (2015) }\end{array}$ & $\begin{array}{l}\text { The authors built this report based on a situation, which was a trigger for active teaching methodologies } \\
\text { implementation. It is mentioned that the situations were evaluated by teachers and students, and improvements } \\
\text { were promoted. }\end{array}$ \\
\hline $\begin{array}{l}\text { Christofoletti } \\
\text { et al. (2014) }\end{array}$ & $\begin{array}{l}\text { Active learning methodology techniques were applied to an Ethics in Health course, reinforcing the importance } \\
\text { of applying active teaching methods in the university environment. The study also highlighted satisfaction of } \\
\text { the students. }\end{array}$ \\
\hline $\begin{array}{l}\text { Melo \& Sant'Ana } \\
(2012)\end{array}$ & $\begin{array}{l}\text { They analyzed the advantages and weakness of the active methodology. They reported the understanding of } \\
\text { students as authors of the learning process. }\end{array}$ \\
\hline Duarte et al. (2013) & $\begin{array}{l}\text { They demonstrated that PBL is applied in the teaching of basic sciences, developing reasoning and encouraging } \\
\text { the pursuit of knowledge through self-directed study. }\end{array}$ \\
\hline Frezatti et al. (2016) & $\begin{array}{l}\text { It was used the active methodology in discipline managed from the perspective of PBL, given the complexity of } \\
\text { synergetic perspective of KSA (Knowledge, Skills, and Attitudes). }\end{array}$ \\
\hline Queiroz et al. (2016) & $\begin{array}{l}\text { They described a university experience with PBL. The results presented in technological innovation projects } \\
\text { promoted integration, making the difference in the process of teaching and learning involved in dental education. }\end{array}$ \\
\hline Leon \& Onófrio (2015) & $\begin{array}{l}\text { They showed good results when used PBL in teaching medicine, especially as regards to critical thinking and } \\
\text { technical skills developed by the student. }\end{array}$ \\
\hline Plonski (1992) & $\begin{array}{l}\text { The education methods based on the structured approach are presented, and a practical case study is described, } \\
\text { pointing out the potential applications in the current activities of production engineers. The conclusions arrived } \\
\text { at the needs of inducing production engineers on permanent education after graduate course conclusion. }\end{array}$ \\
\hline
\end{tabular}


of each stage; (iii) present a project and its specifications relating to technical drawing; (iv) building physical models of the project, evaluating the technical and economic viability.

Firstly, the discipline was presented to the students regarding the content and organization. The challenge was given to the groups as a current problem experienced by the society and may have a solution based on projects. The theme "reuse" and "economy" of water was proposed followed by a discussion of how water reuse and water saving would be possible, in an attempt to collaborate with the preservation of the environment and society. The specification "cisterns to capture rainwater" was the choice by the students. In this way, the main theme was democracy chosen by the students, and entitled as "Development of a capture system and rainwater treatment in the dependencies of the school".

The construction of physical models is a key step for the project-based learning once one of the project phases is the construction of models (Mockups) and prototypes, which has the function to test both, form and function. At this stage, students built models of solids from the planning of their surfaces. This is a very important stage for the process of teaching and learning as provides an effective contact between the student and the object of study through the experience of manufacturing and actual three-dimensional experience. All students built their models using low-cost materials.

All the groups showed their prototype on the day and place previously scheduled by the teacher. The prototypes were retained by the school for future exhibitions. The following material was utilized during the development of the prototypes: (i) initial hand sketches: pencil, paper, rubber, compass, square, among other basic features; (ii) shaped pieces: blocks, pieces patterns, modeling sponges; (iii) free software: FreeCAD ${ }^{\circledR}$ and Google Sketch $\mathrm{Up}^{\oplus}$; (iv) hardware: software classes were held in classrooms with computers organized by group ( 1 machine for each group).

The purpose of the Technical Drawing discipline in High School is the accurate and absolute representation of the forms in the three-dimensional material world. This is important to enable the spatial reconstruction of the form in drawing in the plan and the project, as a concise and unequivocally mean of communication in projects. National and international standards must be followed. The reason for this discipline is the need for preparation of the technical course of the student to the challenge of interpretation and creativity in the abstract and graphic presentation from two and three-dimensional elements. It is through technical design, arrives at the project detailing.

Students should understand the project, formulate hypotheses and formulate learning objectives, representing the knowledge that the group defines as necessary to compose the project. Every week there was a practice section and a theoretical section, as follows:

- Week 1-Introduction to Technical Drawing: presentation of the history and importance of drawing, from the past up to now. The great geniuses such as 
Leonardo da Vinci (importance in engineering and art) Steve Jobs (importance design and usability) were presented. In a practical class; students were encouraged to present applications and reports of good and bad use of drawing highlighting its importance;

- Week 2-Applications of Technical Drawing: Applications such as flowcharts, mechanical design, architectural, pipes, automation, electro electronics and others, were presented. It was followed by a discussion about the importance of knowing how to read and make an interpretation of the drawing as professional engineering;

- Week 3-Presentation of PBL and projects were chosen by students: The teaching methodology based on projects was presented, highlighting its importance in the process of teaching and learning. The schedule and forms of assessment were also presented and agreed with the students. The presentation was very receptive, once "put your hands on" is faced by students as an excellent approach. After the presentation, the groups were divided, and the project rules were given;

- Week 4-Design by Canvas: Canvas (Naggar, 2015) was presented as a design model. The mission of insert the project in Canvas was assigned to students. They had five weeks to present the final version. Therefore deadline was week 9;

- Week 5-Symbology and Standards: Standards and necessary technical drawing symbols were presented and a discussion of the importance of these rules were carried out with students;

- Week 6-Geometric Constructions: Theory was presented to students in addition to written exercises. Analytic geometry concepts and use of square and compasses were taught;

- Week 7-Plans and Projections: Theory was presented to students in addition to written exercises;

- Week 8-Sheet and Subtitles: sheets were presented in various sizes, with folding practices and building legends;

- Week 9-Practice Evaluation: Presentation of Canvas previously assigned on week 4 was performed in this class. The activity was conducted with the presentation of the groups. Post-it was utilized to insert information at each stage of the project subject (Figure 1).

- Week 10 - 17-Theory Contents: The subjects scales, dimensions, views and perspectives, auxiliary views, courts, sessions, tolerances, and adjustments were presented with their practices using the online workbook. Students seek the reading and interpretation of Technical Drawing front of the exercises. The workbook was based on the book "Drawing Course Technical and Autocad" (Ribeiro et al., 2013). This is an important engineering book, leading the High School and Technical students at the highest level of education. The workbook exercise example is shown in Figure 2.

- Week 19-Theoretical Assessment and Projects Delivery-Drawing Manual: 


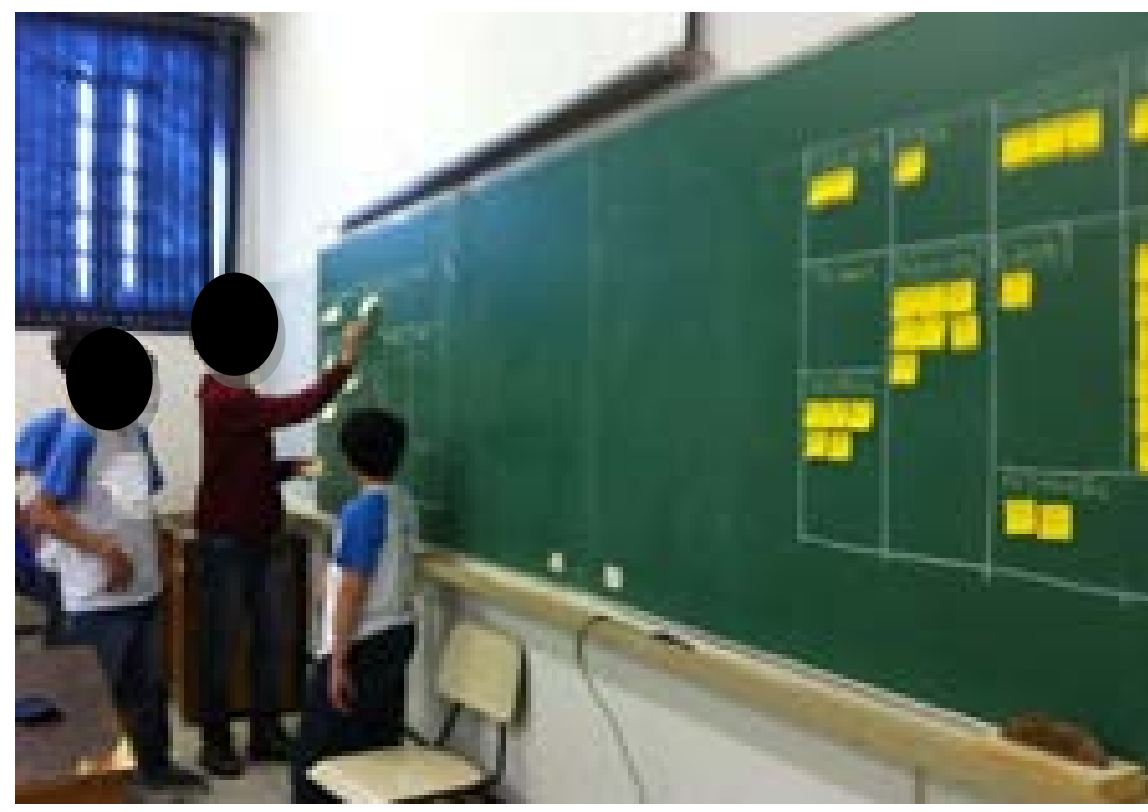

Figure 1. Presentation of the PMC by students.

By the end of 40 hours, a written test with questions of importance on Technical Drawing in dichotomous and trichotomous format, multiple choice and dissertation questions on the matters related the main commonalities of Technical Drawing was performed. At this point, the course reported in this paper turns similar to the end of the major courses offered in High School, in which an assessment is performed by the end of the course ( 80 hours). In this class, students also presented the manual drawing of the parts that would make up the cistern project. The number of pieces was according to the complexity of the project. Therefore, a minimum of 3 parts (pieces) was required for each group;

- Week 20 and 21-Modeling in Sponge: An excellent practice of spatial visualization and representation of views and projections is to build three-dimensional blocks made by material type floral sponge or soap from representations of two-dimensional views. Students reproduced the pieces, which were given in printed exercises in moldable block (class 20) and performed the reverse activity (class 21) (Figure 3).

- Week 22-Assembly Drawing: Drawing of joint and assembly were explained in their theoretical and practical Reading (Figure 4).

- Week 23-Surface Elements: Subject usually explored in engineering degree courses were explained in their theoretical and practical reading.

- Week 24 to 28 -From week 24 the teaching computer-aided was included. The classesaborded the main software, focusing on free software like Freecad ${ }^{\star}$ and Google Sketch Up in their free limited version. Students took lessons in computer labs or personal computers and learned about the use and comparison of the software. The drawings of pieces, assemblies, and printing were showed in theoretical-practical classes. 

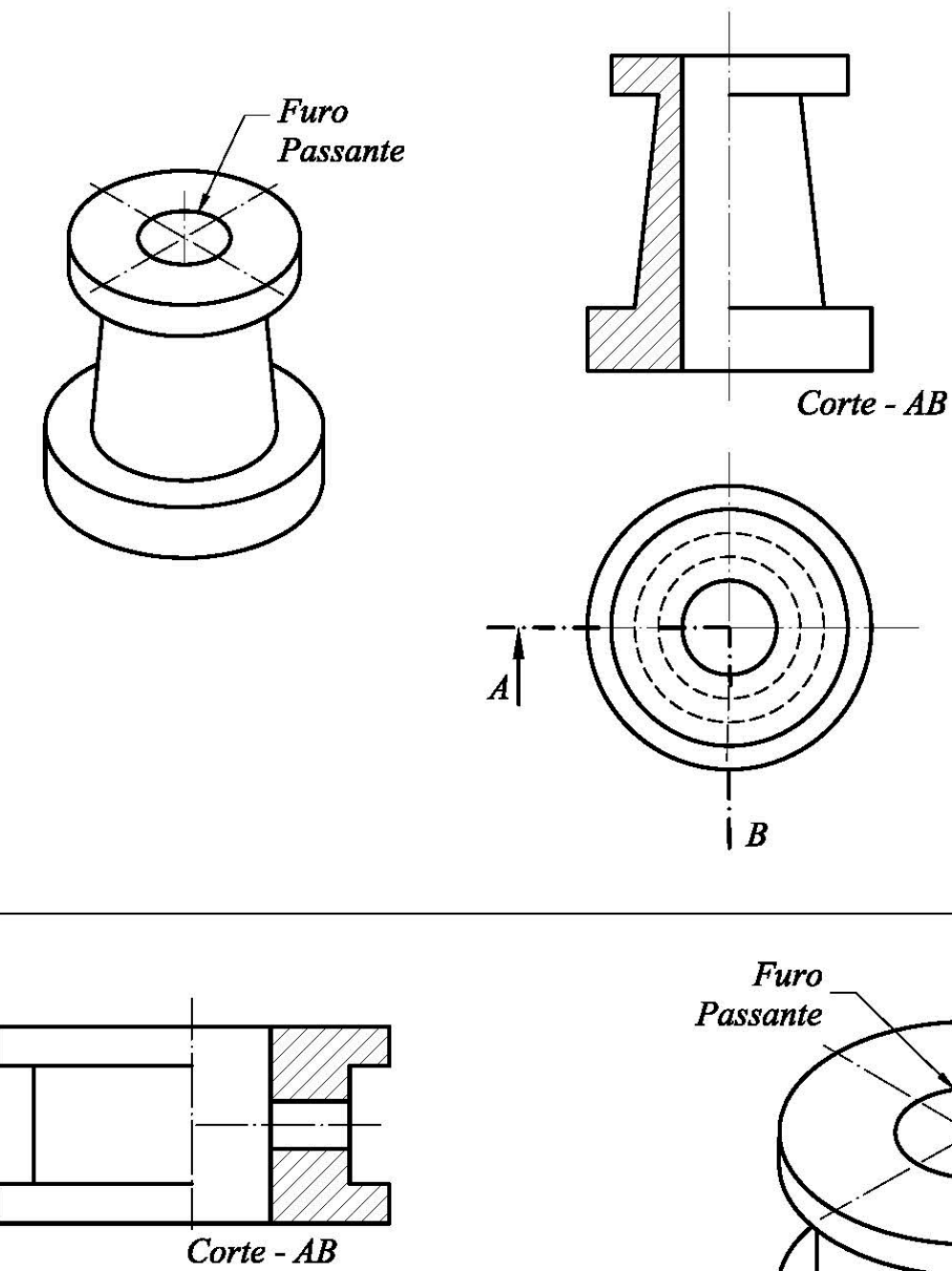

Furo
Passante
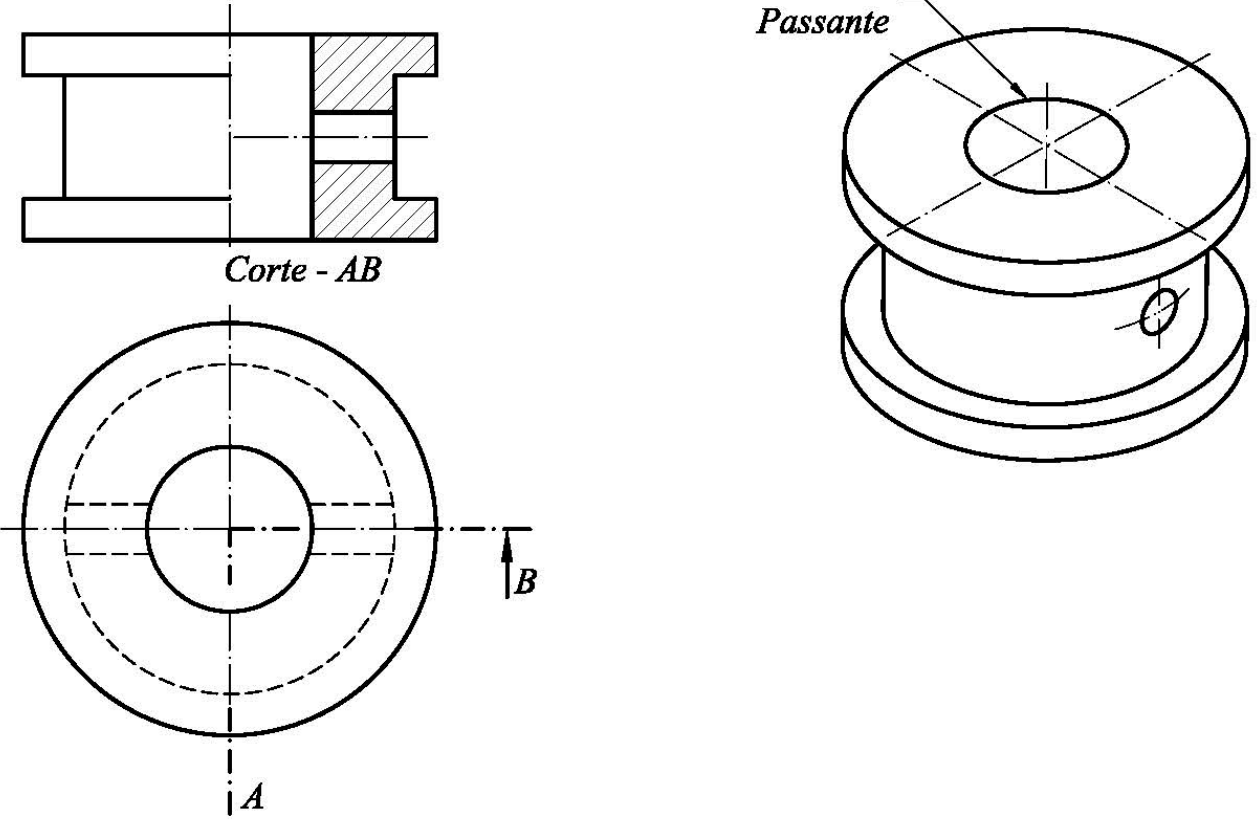

\begin{tabular}{|c|c|c|c|c|c|}
\hline ITEM & DENOI & Qdade. & MATERLAL & \multicolumn{2}{|c|}{ DIMENSO OES } \\
\hline \multicolumn{4}{|c|}{ CURSO DE DESENHO TÉCNICO } & \multicolumn{2}{|c|}{$T C / T S-23$} \\
\hline Nome & & \multirow{2}{*}{\multicolumn{3}{|c|}{\begin{tabular}{|l|} 
Titulo \\
PROJEÇÕES EM CORTE \\
$\begin{array}{c}\text { Dadas as vistas superiores, completar as vistas defrente } \\
\text { aplicando os meios cortes indicados nos desenhos. }\end{array}$ \\
\end{tabular}}} & Nota \\
\hline Número & Turma & & & & Pro \\
\hline
\end{tabular}




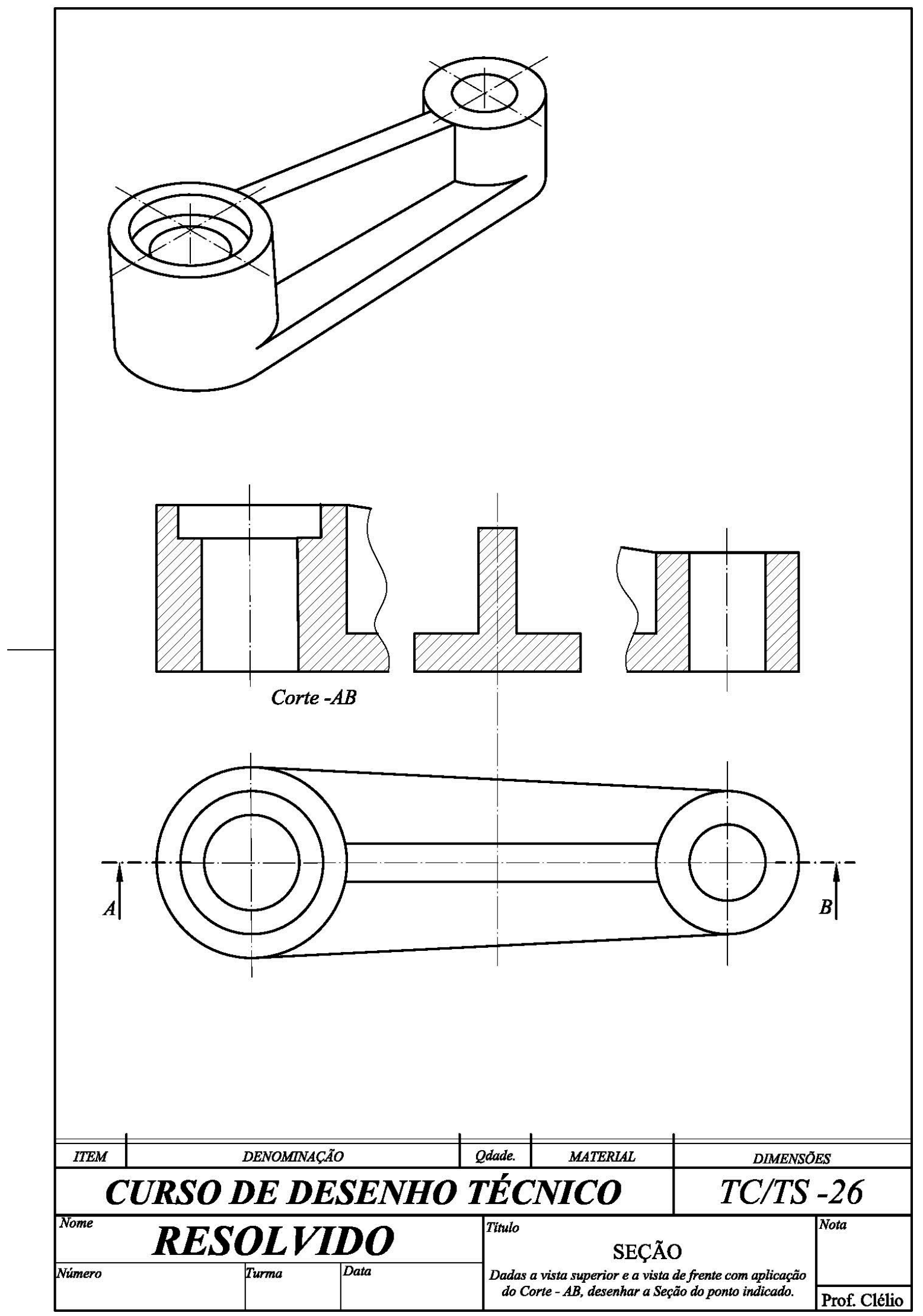

Figure 2. Handout design. 

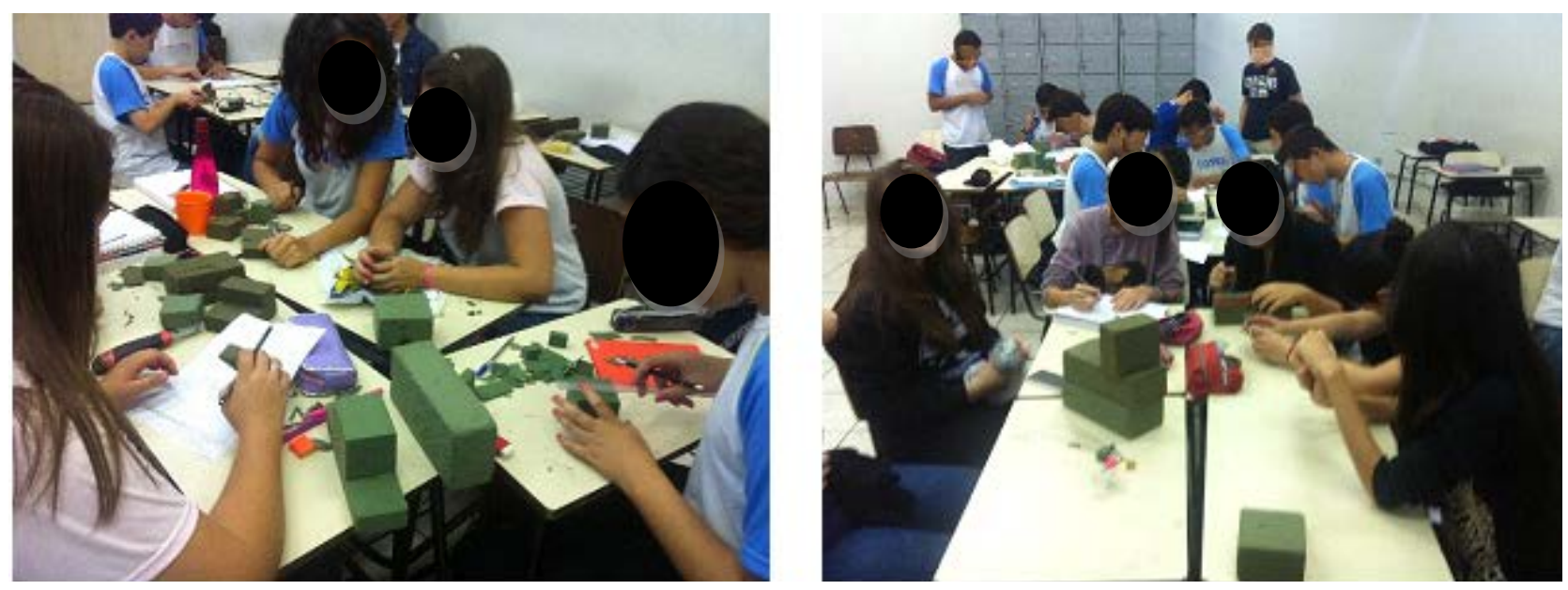

Figure 3. Modeling activities block.

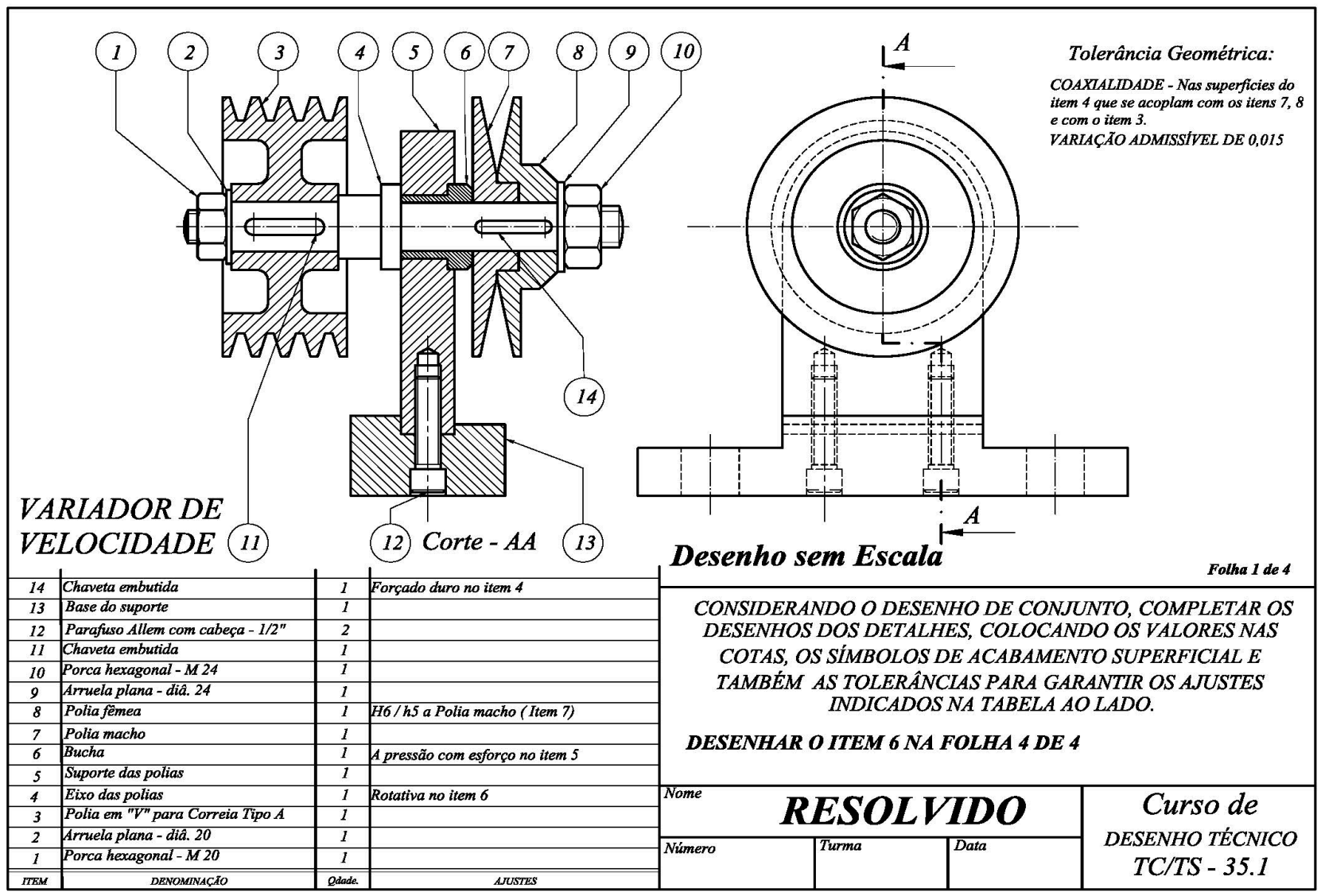

Figure 4. Assembly drawing.

- Week 29-Project editor and the Project Delivery CAD: Students learned project instruction utilizing a scientific paper and a poster template. The work was later presented at a Science Fair.

- Week 30-Models and Mockup Project: In this lesson, there was an exposure of resources to be used for building models. There was a focus on sustainability, with low use of financial resources and use of recycled materials in the 
project.

- Week 31-Practice activity in the construction of mockup and project closure: Students built or adjusted details of their models in the classroom with the help of teachers and monitor of the discipline.

- Week 32 and 33-Theory of Analysis of Failure in Projects: Projects may fail. A class about techniques of risk analysis in projects using tools, such as the tree of causes and the cause-and-effect diagram was performed. Groups were instructed to predict failures in their projects.

- Week 34 and 35-Presentation of Projects and mockups in the Classroom: Students present their projects for the other groups in the classroom.

- Week 36-Presentation of mockups in Science Fair: In the Science Fair event, the institution opens the doors to the community for the presentation of Technical Course projects. A room was reserved exclusively for the Technical Drawing project. Teachers of other subjects were asked to evaluate the quality of the projects (Figure 5). The event lasted three days (morning and afternoon) and received over a thousand visitors.

- Week 37-Monitoring: After the presentation it was performed a discussion about the projects and mockups, taking into account the comments of the evaluators and the analysis of failure performed at weeks 32 and 33;

- Week 38 and 39-Presentation of Final Reports of Projects: Projects in poster format were presented by the students, with a time of 10 minutes per group (Figure 6).

- Week 40-Project Closing: Reports and discussions about learning during the year were conducted, and a questionnaire for evaluation of the discipline and method was applied. Engineering applications were presented by other teachers, for example, an automation mockup (Figure 7(a)) and a real cistern which was implemented from the projects developed in class (Figure 7(b)).
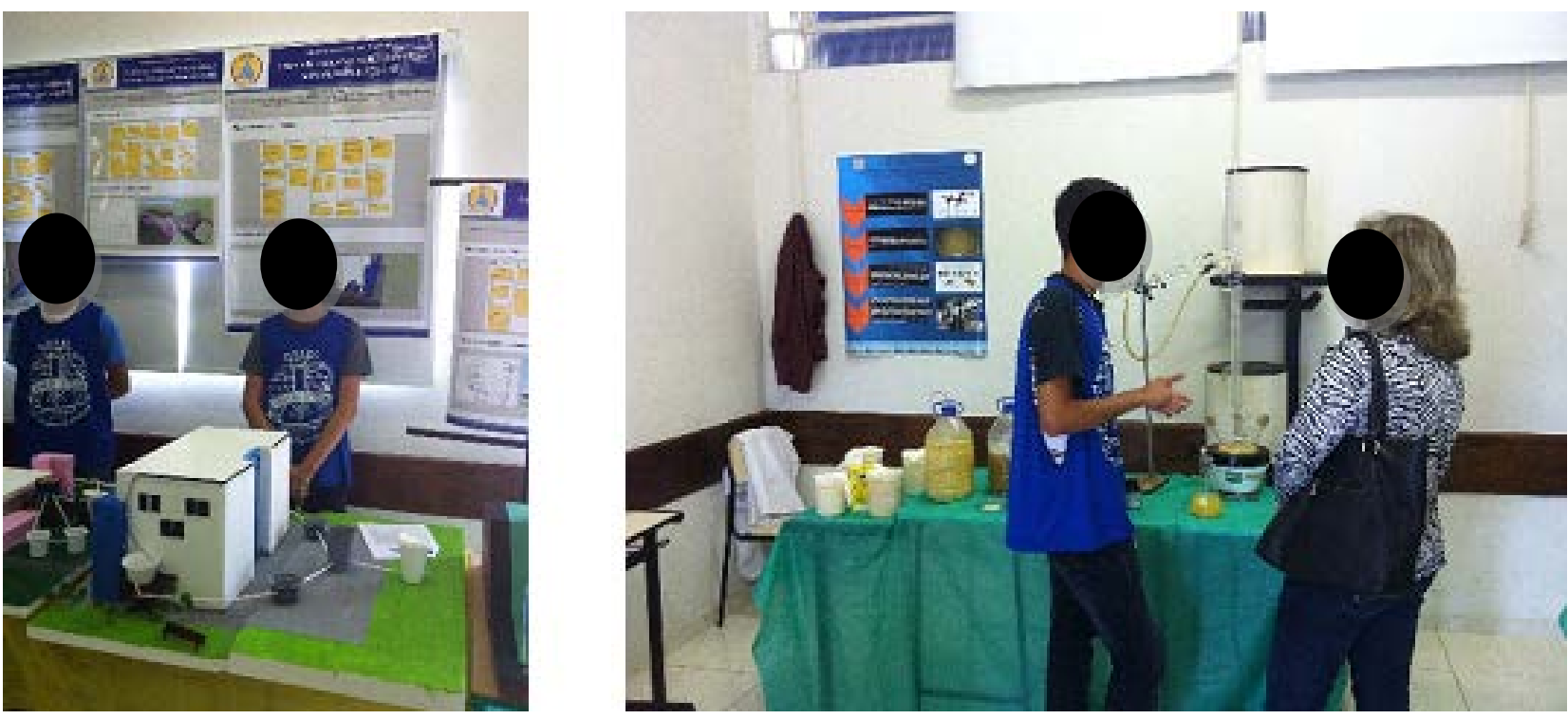

Figure 5. Presentation at science fair. 


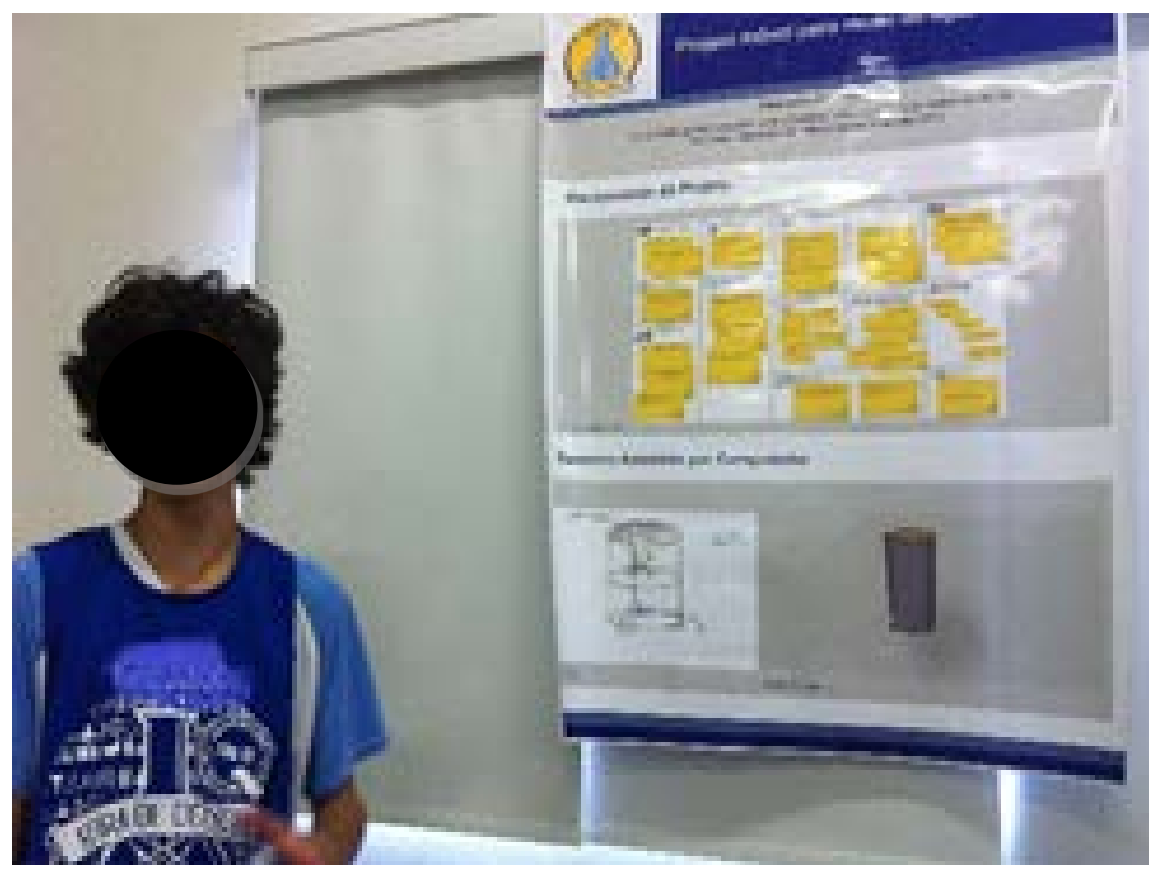

Figure 6. Presentation of posters.

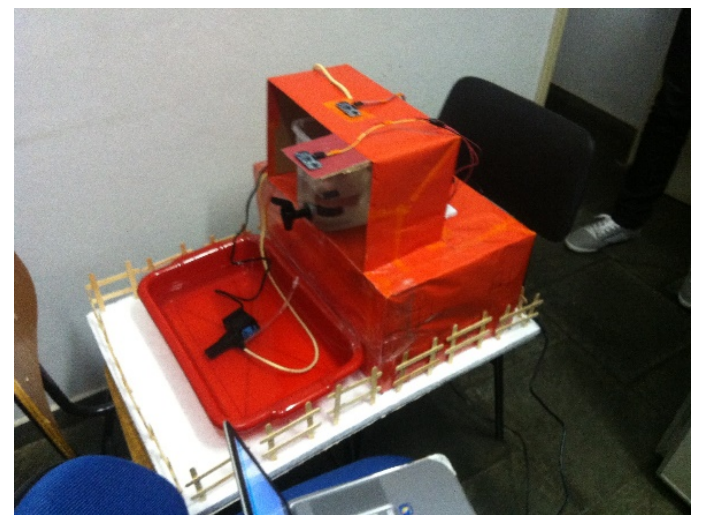

(a)

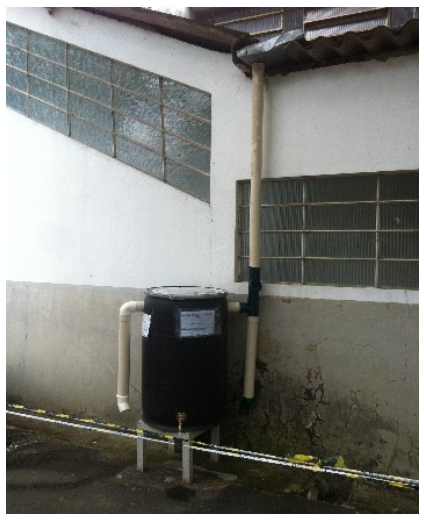

(b)

Figure 7. Mockup of cistern (a) and real cistern (b).

A news report was developed by regional news (TV Vanguard), where activities were presented, and a student was interviewed (Figure 8).

During the whole period, control points (checkpoints) were established for the formal control of the progress of the project, similar to what occurs in professional life, in which goals and deadlines are part of the professional routine. These controls set the pace of progress of the project, keeping some freedom of action for the teams. The objective was to control basic aspects of the implementation of the project so that the rhythm of work to be done could flow properly. Also, support material to be used during the course was available on the internet, and the communication with the leader was possible through the social network.

At the end of the discipline, it was given to the students the opportunity to 


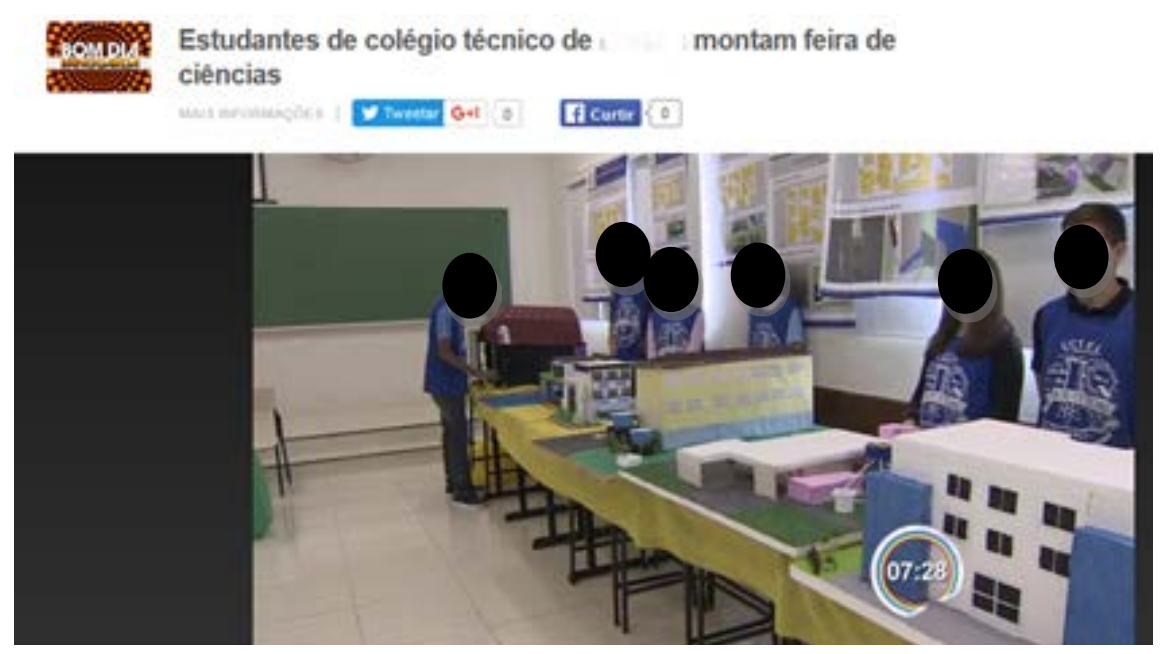

Figure 8. Interview on TV Vanguarda.

give their opinion about the method, their commitment, and participation. The question: "Would you like to be the monitor of Technical Drawing discipline next year?" was answered as "yes" by 31 of the 34 respondents, reflecting the interest acquired by them. The justification included:

"Yes, because I thought I would feel a lot of trouble with the programs and manual drawings, but $P \mathrm{~m}$ doing better than I thought. I enjoyed working with projects. It is something that I had never done, so I think my help can be somewhat usefup".

"Yes, the matter gives a very good background for college and 1 ve enjoyed it."

"Yes, because I liked this method of learning and I would like to spend a little of what I learned this year to another student."

"To be a monitor next year would be my pleasure. During the year I got attached to the discipline, and I also reinforced my aspiration to become an architect, civil engineer or mechanical engineer."

"Yes, because I liked to use creativity to make innovative projects." In addition to this, it was suggested to the students to "Let your criticism or suggestions regarding projects by learning method":

"The project was very good for our learning."

"I liked the teacher's availability for service to answer questions about the matter."

"Professor and monitor were always very attentive, provide the time to answer our questions and provide support."

"It was interesting to have class this way, something quite different from the materials with which I was used to."

"In my opinion, the idea of developing projects was very good."

"I think it should be proposed something even more innovative. The subject was great. However almost all the groups used the same solution. I think that innovation should be placed as an even more important re- 


\section{quirement (and also technology)."}

Considering the verbalizations, it's possible to conclude that the students were interested in the discipline in addition to the teaching method. Moreover, some of them got inspired and open to take place as a monitor and work harder on new projects, or even follow the career in Engineering and Technology.

\section{Conclusions and Considerations}

Several papers have already been published demonstrating gains in the implementation of active teaching and learning methodologies. However it rarely finds application in a full discipline. Some disciplines are more suitable to the PBL than others. Therefore there is not a recipe to solve the education and teaching practice problems, neither a pattern, due to the teaching practices cover many variations and adaptations. Disciplines based on projects, such as Technical Drawing, seem to be relatively more suitable. On the other hand, it's mandatory to keep full attention on theoretical content during the implementation.

Besides the knowledge acquired, the development of projects allows students to contribute socially. All participants demonstrated sufficient understanding of the concepts in assessments in addition to the concern related to the implementation of the practices and the presentation of the developed project. These results corroborate to an initiative to be developed in education area to promote changes in practices of students and teachers.

Overall, the students had a positive reaction to the PBL, suggesting its possible use in another discipline in an integrated way, since some aspects of the implementation presented here were reconsidered and resized according to the problems and approaches of each application case.

\section{References}

Ausin, V., Abella, V., Delgado, V., \& Hortigüela, D. (2016). Aprendizaje Basadoen Proyectos a través de las TIC: Una Experiencia de Innovación Docente desde las Aulas Universitarias. Formaciónuniversitaria, 9, 31-38.

Campello, A. D. V. C., \& Lins, L. N. (2008). Metodologia de análise e tratamento da evasão e retencão em cursos de graduacão de instituicões federais de ensino superior. XXVIII Encontro Nacional de Engenharia De Producão, RJ, 13. http://www.abepro.org.br/biblioteca/enegep2008_TN_STO_078_545_11614.pdf

Cao, Y., Lu, Y., Yao, H., \& Cheng, H. (2013). CAD Education Resource Platform for Mechanical Design and Manufacture. Research Journal of Applied Sciences, Engineering and Technology, 5, 3026-3031. http://maxwellsci.com/print/rjaset/v5-3026-3031.pdf https://doi.org/10.19026/rjaset.5.4618

Chao, C. Y, Chen, Y. T., \& Chuang, K. Y. (2015). Exploring Students Learning Attitude and Achievement in Flipped Learning Supported Computer Aided Design Curriculum: A Study in High School Engineering Education. Computer Applications in Engineering Education, 23, 514-526. https://doi.org/10.1002/cae.21622

Christofoletti, G., Fernandes, J. M., Martins, A. S., Oliveira Jr., S. A., Carregaro, R. L., \& Toledo, A. M. (2014). Grau de satisfação discente frente a utilização de métodos ativos de aprendizagem em uma disciplina de Ética em saúde. Revista Eletrônica de Educação, 


\section{8, 188-197. https://doi.org/10.14244/19827199823}

Dos Santos, A. P., Nascimento, C., \& Rios, J. R. T. (2000). Estudo da evasão e da retencão nos cursos de engenharia da Escola de Minas da Universidade Federal de Ouro Preto. In Cobenge 2000. http://www.abenge.org.br/CobengeAnteriores/2000/artigos/175.PDF

Dolmans, D., \& Gijbels, D. (2013). Research on Problem-Based Learning: Future Challenges. Medical Education, 47, 214-218. https://doi.org/10.1111/medu.12105

Duarte, A. L. A., Monaco, C. F., \& Manso, M. E. G. (2013). A Aprendizagem baseada em Problemas no Ensino de Ciências Básicas: experiência no segundo semestre do curso de Medicina de um Centro Universitário. Revista O Mundo da Saúde, 37, 89-96.

http://www.saocamilo-sp.br/pdf/mundo_saude/101/9.pdf https://doi.org/10.15343/0104-7809.20133718996

Frezatti, F., Borinelli, M. L., Martins, D. B., \& Espejo, M. M. S. B. (2016). Análise do Desempenho de alunos na Perspectiva do CHA em Disciplina utilizando PBL: O que significa a síntese? Revista de Contabilidade e Organizaçôes, 10, 3-19.

Granzotti, G., \& Barroso, R. (2015). Problem-Situation as a Trigger of the Teaching-Learning Process in Active Teaching Methodologies. Revista CEFAC, 17, 2081-2087.

Hung, P. H., Hwang, G. J., Lee, Y. H., Wu, T. H., Vogel, B., Milrad, M., \& Johansson, E. (2014). A Problem-Based Ubiquitous Learning Approach to Improving the Questioning Abilities of Elementary School Students. Journal of Educational Technology \& Society, 17, 316-334. http://www.learntechlib.org/p/156109

Jerzembeka, G., \& Murphya, S. (2013). A Narrative Review of Problem-Based Learning with School-Aged Children: Implementation and Outcomes. Educational Review, 65, 206-218. https://doi.org/10.1080/00131911.2012.659655

Kim, D. G., \& Lee, J. (2014). A Study on Improving Information-Processing Abilities Based on PBL. Turkish Online Journal of Distance Education, 15, 41-52 https://doi.org/10.17718/tojde.18487

Kolmos, A., De Graaff, E., \& Du, X. (2009). Diversity of PBL:-PBL Learning Principles and Models. Research on PBL Practice in Engineering Education (Vol. 4). https://doi.org/10.7771/1541-5015.1180

Lee, D., Huh, Y., \& Reigeluth, C. M. (2015). Collaboration, Intragroup Conflict, and Social Skills in Project-Based Learning. Instructional Science, 43, 561-590. https://doi.org/10.1007/s11251-015-9348-7

Leon, L. B., \& Onófrio, F. Q. (2015). Aprendizagem Baseada em Problemas na Graduação Médica-Uma Revisão da Literatura Atual. Revista Brasileira de Educação Médica, 39, 614-619. https://doi.org/10.1590/1981-52712015v39n4e01282014

Lins, L. M., Salerno, M. S., Araújo, B. C., Gomes, L. A. V., Nascimento, P. A. M. M., \& Toledo, D. (2014). Escassez de engenheiros no Brasil? Uma proposta de sistematização do debate. Novos Estudos-CEBRAP, 98, 43-67. https://doi.org/10.1590/S0101-33002014000100004

Long, T., \& Qin, D. (2014). Challenges of Conducting Problem-Based Learning in a Large Class. Chinese Education \& Society, 47, 106-110. https://doi.org/10.2753/CED1061-1932470312

Melo, B. C., \& Sant’Ana, G. (2012). A prática da Metodologia Ativa: Compreensão dos discentes enquanto autores do processo ensino-aprendizagem. Revista Ciências e Saúde, 23, 327-339.

http://www.escs.edu.br/pesquisa/revista/2012Vol23_4_5_ApraticaMetodologiaAtival.pdf

Meyer, P. A., \& Nascimento, M. (2011). Há escassez generalizada de profissionais de carreiras técnico-científicas no Brasil? Uma análise a partir de dados do CAGED. 
Revista mercado de trabalho: Conjuntura e análise, 49, 19-28. http://repositorio.ipea.gov.br/handle/11058/3908

Moreno, M. A., Reis, M. J., \& Calefi, P. S. (2013). Concepções de professores de Biologia Física e Química sobre aprendizagem baseada em Problemas. Revista Hipótese, Itapetininga, 2, 104-117. http://itp.ifsp.edu.br/ojs/index.php/HIP/article/view/284

Naggar, R. (2015). The Creativity Canvas: A Business Model for Knowledge and Idea Management. Technology Innovation Management Review, 5, 50-58. http://timreview.ca/article/914

Nanda, B., \& Manjunatha, S. (2013). Indian Medical Students' Perspectives on Problem-Based Learning Experiences in the Undergraduate Curriculum: One Size Does Not Fit All Nanda, Bijli, Manjunatha, Shankarappa. Journal of Educational Evaluation for Health Professions, 31, 10-11.

Pena, F. L. A. (2012). Sobre a presença do Projeto Harvard no sistema educacional brasileiro. Revista Brasileira de Ensino de Física, 34, 1-4. https://doi.org/10.1590/S1806-11172012000100016

Pereira, M. A. C., Barreto, M. A. M., \& Pazeti, M. (2017). Application of Project-Based Learning in the First Year of an Industrial Engineering Program: Lessons Learned And Challenges. Production, 27, e20162238. https://doi.org/10.1590/0103-6513.223816

Plonski, G. A. (1992). Inovando métodos na educação continuada dos engenheiros de produção. Production, 2, 71-80. https://doi.org/10.1590/S0103-65131992000100006

Queiroz, J. R. C., Oliveira, M. F. J., Souza, D. M. C., Araújo, A. L. L. S., \& Fuscella, M. A. P. (2016). Aprendizagem por Projeto e Inovação Tecnológica: União por Competências. Revista ABENO, 16, 2-6.

http://revabeno.emnuvens.com.br/revabeno/article/view/243

Ribeiro, A. C., Peres, M. P., \& Izidoro, N. (2013). Curso de Desenho Técnico e Autocad-Editora Pearson. http://loja.pearson.com.br/auto\%20cad

Santos, E. F., \& Lima, C. A. C. (2012). DMAICR in an Ergonomic Risks Analysis. Work, 41, 1632-1638.

Santos, E. F., Pereira, C., Auxiliadora, M., Barreto, M., \& Silva, M. B. (2017). Parceria Universidade e Hospital Para a Melhoria dos Processos Através do Lean Healthcare. In Xlv Cobenge-Congresso Brasileiro de Ensino em Engenharia.

http://www.abenge.org.br/sis_submetidos.php?acao=abrir\&codigo=COBENGE17_000 20_00000415.pdf

Santos, E. F., Robeiro, T. J. G., Silva, M. B., Pereira, M. A. C., \& Silva, A. V. F. M. (2015). Proposta de uma metodologia baseada em projetos na disciplina de controle $e$ automação no curso de engenharia de produção. In Anais do XXII Simpósio de Engenharia de Produção-SIMPEP. SIMPEP/UNESP.

Santos, E. F., Silva, M. B., \& Barreto, M. A. M. (2015). Proposta de uma estratégia de ensino-aprendizagem na disciplina de desenho técnico utilizando software livre e metodologia baseada em projetos. In N. Hattum-Janssen, R. M. Lima, D. Carvalho, S. Fernandes, R. M. Sousa, F. Moreira, N. A. Arexolaleiba et al. (Eds.), Proceedings of 17th International Symposium on Project Approaches in Engineering Education (pp. 479-486). San Sebastian: Aalborg University Press.

Silva, C. C. M., Silva, J. J. D., Jorge, E. M. F., Santos, D. A., \& Saba, H. (2016). A Revolução da Robótica utilizando lixo eletrônico no Ensino Básico: Formação Ampliada e menor Vulnerabilidade de Jovens à Violência nas escolas Públicas. Revista do Laboratório de Estudos da Violência e Segurança da UNESP/Marília, 17, 75-89. http://www2.marilia.unesp.br/revistas/index.php/levs/article/view/5973/4011 
Tan, L. T., Goh, B., \& Yap, N. W. (2015). Project-Based Learning: Engaging Secondary School Students in Authentic Environmental Science Research. Asian Youth Journal of Biology, 3, 1-4. http://hdl.handle.net/10497/16879

Wiek, A., Xiong, A., Brundiers, K., \& Van Der Leeuw, S. (2013). Integrating Problem and Project-Based Learning into Sustainability Programs: A Case Study on the School of Sustainability at Arizona State University. International Journal of Sustainability in Higher Education, 15, 431-449.

Wilder, S. (2015). Impact of Problem-Based Learning on Academic Achievement in High School: A Systematic Review. Educational Review, 67, 411-435. https://doi.org/10.1080/00131911.2014.974511

Ye, X., Peng, W., Chen, Z., \& Cai, Y. (2014). Today's Students, Tomorrow's Engineers: An Industrial Perspective on CAD Education Computer-Aided Design, 36, 1451-1460. 